dom, for their helpful advice, and Deo Persaud, Cordis, United Kingdom, for providing technical assistance.

1. Arapov AD, Vishnerskii AA Jr, Abdullaev FZ, Korchagin VA, Mirtskhulava $\mathrm{KA}$, Sorgin ME. A preliminary report on laser application in cardiosurgery. $E k s p$ Khir Anesteziol 1974:4:10-12.

2. Macruz R, Martins JRM, Tupinnamba HS, Lopes EA, Varbas H, Penna AF, Carvalho VB, Armetin E, Decourt LV. Possibilidades terapeuticas do raio laser em ateromas. Arq Bras Cardiol 1980;34:9-12.

3. Riemenschneider TA, Lee G, Ikeda RM, Bommer WJ, Stobbe D, Ogata C, Rebeck K, Reis RL, Mason DT. Laser irradiation of congenital heart disease: potential for palliation and correction of intracardiac and intravascular defects. Am Heart J 1983;106:1389-1393.

4. Ginsburg R, Wexler L, Mitchell RS, Proffit D. Percutaneous transluminal laser angioplasty for treatment of peripheral vascular disease. Clinical experiente with 16 patients. Radiology 1985;156:619-624.

5. Samborn TA, Cumberland DC, Welsh CL, Greenfield AJ, Guben JK. Percutaneous laser thermal angioplasty: initial results and 1 year follow-up in 129 femoropopliteal lesions. Radiology 1988;168:121-125.

6. Kirklin JW, Barratt-Boyes BG. Cardiac surgery. New York: John Wiley, 1986:821-856

7. Kirklin JW, Blackstone EH, Shimaznki Y, Maehara T, Pacifico AD, Kirklin $\mathrm{JK}$, Bargeron LM Jr. Survival, functional status, and reoperations after repair of tetralogy of Fallot with pulmonary atresia. J Thorac Cardiovasc Surg 1988 96:102-116.

\title{
Atherectomy of Right Coronary Ostial Stenoses: Initial and Long- Term Results, Technical Features and Histologic Findings
}

Jeffrey J. Popma, MD, Ronald J. L. Dick, MBBS, Christian C. Haudenschild, MD, Eric J. Topol, MD, and Stephen G. Ellis, MD

C ronary angioplasty of lesions involving the right coronary ostium has been limited by suboptimal early success and by high rates of both acute complications and late restenosis. ${ }^{1}$ In nonostial stenoses, directional coronary atherectomy appears to result in larger residual coronary dimensions than does coronary angioplasty ${ }^{2}$ and may provide a potentially improved long-term outcome. To determine the immediate and long-term angiographic results of directional atherectomy in patients with right ostial stenoses, we attempted this procedure in 7 consecutive patients with coronary stenoses within 3 $\mathrm{mm}$ of the right coronary ostium.

Seven patients with New York Heart Association functional class III to IV angina were referred to the University of Michigan Medical Center for nonsurgical revascularization of stenoses involving the right coronary ostium. One to 4 months before detection of the ostial stenoses, 3 patients had coronary angioplasty of the midright coronary artery. After intracoronary nitroglycerin, all patients had a stenosis $>50 \%$ in diameter within $3 \mathrm{~mm}$ of the orifice of the right coronary artery. ${ }^{I}$

After informed consent and pretreatment with aspirin, a calcium antagonist and 10,000 to 15,000 $\mathrm{U}$ of intravenous heparin, a 9.5 to $11 \mathrm{Fr}$ guiding catheter (Devices for Vascular Intervention, Inc., Redwood City, California) was advanced to the right coronary ostium. $A$ 0.014 -inch coronary guidewire was positioned across the coronary stenosis and predilation performed with an undersized standard angioplasty balloon (Figure 1). A 5 to 7 Fr atherectomy device (Devices for Vascular Intervention, Inc.) was then positioned across the right coronary ostium and the guiding catheter was withdrawn into the ascending aorta. Coronary atherectomy was then performed by the method previously described ${ }^{3}$ until a sat-

From the Department of Internal Medicine, Division of Cardiology B1F245, University of Michigan Medical Center, 1500 E. Medical Cente Drive, Ann Arbor, Michigan 48109-0022, and the Cardiovascular Research Laboratory, Mallory Institute of Pathology, Boston College, Boston, Massachusetts. Manuscript received September 17, 1990; revised manuscript received and accepted October 25, 1990. isfactory angiographic result was obtained. Patients were monitored for evidence of abrupt closure and intravascular sheaths were removed within 12 hours. Successful atherectomy was defined as a $<50 \%$ residual stenosis, tissue removal and the absence of in-hospital ischemic complications. At the time of hospital dis. charge, patients were maintained on aspirin and a calcium antagonist. Repeat coronary arteriography 6 months after the procedure was recommended.

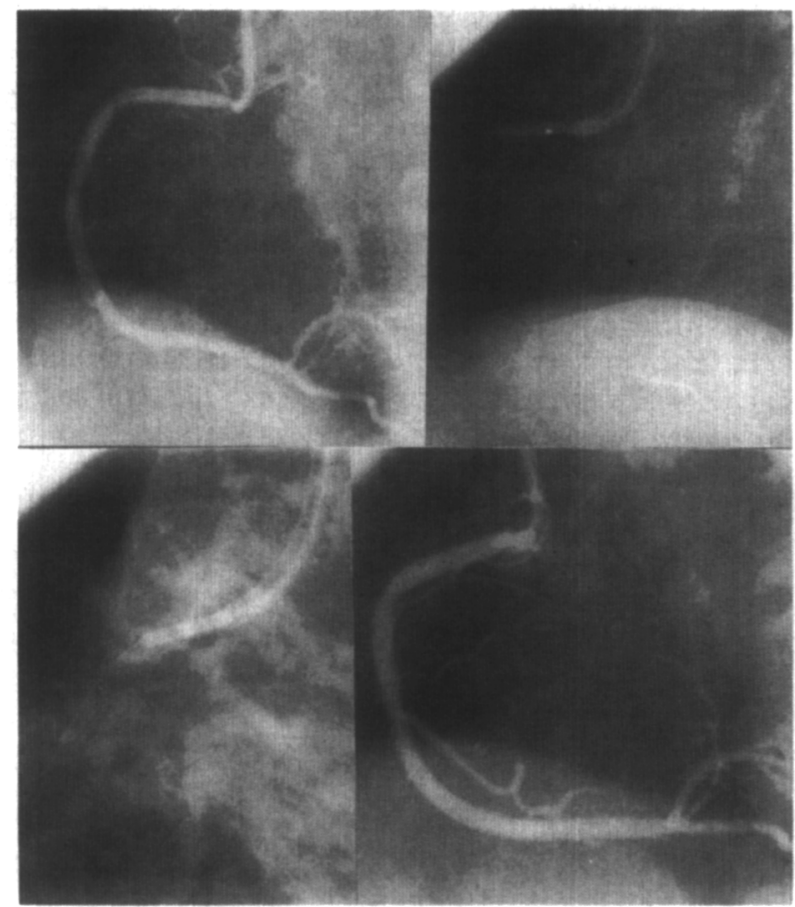

FIGURE 1. Top left, left anterior oblique projection of a right coronary ostial lesion. Note streaming artifact from inability to fill the distal vessel adequately. Top right, after predilation with an undersized balloon catheter, the atherectomy device is positioned in the coronary ostium and the guiding catheter is withdrawn slightly (lower left). The coronary ostium is widely patent immediately after coronary atherectomy (lower right), 


\begin{tabular}{|c|c|c|c|c|c|c|}
\hline \multirow[b]{2}{*}{ Patient } & \multirow[b]{2}{*}{$\begin{array}{l}\text { Age (yr) } \\
\& \text { Sex }\end{array}$} & \multirow{2}{*}{$\begin{array}{l}\text { Coronary } \\
\text { Calcium } \\
(0-3+)\end{array}$} & \multirow{2}{*}{$\begin{array}{l}\text { Lesion } \\
\text { Length } \\
\text { (mm) }\end{array}$} & \multicolumn{3}{|c|}{ Percent Diameter Stenosis (minimal diameter $[\mathrm{mm}]$ ) } \\
\hline & & & & $\begin{array}{l}\text { Before } \\
\text { (MD mm) }\end{array}$ & $\begin{array}{l}\text { After } \\
(\mathrm{MD} \mathrm{mm})\end{array}$ & $\begin{array}{l}\text { Follow-Up } \\
\text { (MD mm) }\end{array}$ \\
\hline 1 & $67 \mathrm{M}$ & $1+$ & 2.0 & $63(1.8)$ & $17(3.4)$ & $18(2.8)$ \\
\hline 2 & $72 \mathrm{~F}$ & $2+$ & 1.4 & $56(2.1)$ & $0(4.0)$ & $13(3.1)$ \\
\hline 3 & $62 M$ & $2+$ & 11.1 & $72(1.1)$ & $46(1.7)$ & $78(0.7)$ \\
\hline 4 & $45 M$ & $2+$ & 3.3 & $58(1.8)$ & $0(4.1)$ & $10(4.3)$ \\
\hline 5 & $72 \mathrm{~F}$ & 0 & 1.0 & $59(2.0)$ & $17(3.3)$ & $0 *(2.4)$ \\
\hline 6 & $78 \mathrm{M}$ & $1+$ & 2.0 & $59(1.2)$ & $6(2.8)$ & $10(2.4)$ \\
\hline Overall & & & & $\begin{array}{c}61 \pm 5 \\
(1.7 \pm 0.4)\end{array}$ & $\begin{array}{c}14 \pm 16 \\
(3.2 \pm 0.8)\end{array}$ & $\begin{array}{c}22 \pm 26 \\
(2.6 \pm 1.1)\end{array}$ \\
\hline
\end{tabular}

Coronary calcific deposits were graded qualitatively on a 0 to 3 scale, with 0 representing no calcific deposits and $1+, 2+$ and $3+$ representing mild, moderate and extensive calcific deposits, respectively. End-diastolic images obtained from the left anterior oblique projection demonstrating the right coronary ostium were used for quantitative coronary analysis, with a computer-assisted automated edge detection system. ${ }^{1}$

After formalin fixation, a hematoxylin/eosin stain was used to assess overall cellularity and specimen morphology. VanGieson/elastin and modified trichrome/ fibrin stains were used to evaluate normal vascular components beyond the internal elastic lamina and thrombotic components, respectively. Quantitative histomorphometric analysis was performed manually on images projected onto a magnetized digitizing tablet. Specimen components were divided into normal vessel wall containing the media, adventitia, lesion and thrombus. The lesion comprised (1) sclerotic, dense collagenic tissue with only scant cellularity, with or without calcification, (2). fibrocellular areas with abundant viable cells, smooth muscle and macrophages, and (3) lipid-rich regions with necrosis and an amorphous extracellular matrix. Each specimen was planimetered in square millimeters and expressed as a percentage of the total specimen area.

TABLE II Histologic Findings in Patients Undergoing Right Ostial Atherectomy

\begin{tabular}{|c|c|c|c|c|c|}
\hline \multirow[b]{2}{*}{ Patient } & \multicolumn{2}{|l|}{ Vessei Wall } & \multicolumn{3}{|c|}{$\begin{array}{l}\text { Atherosclerotic } \\
\text { Plaque }\end{array}$} \\
\hline & $\begin{array}{l}\text { Adventitia } \\
(\%)\end{array}$ & $\begin{array}{l}\text { Media } \\
(\%)\end{array}$ & $\begin{array}{l}\mathrm{FC} \\
(\%)\end{array}$ & $\begin{array}{l}S C L \\
(\%)\end{array}$ & $\begin{array}{l}\text { LD } \\
(\%)\end{array}$ \\
\hline 1 & 5 & 20 & 27 & 41 & 7 \\
\hline 2 & 0 & 15 & 59 & 0 & 26 \\
\hline 3 & 0 & 25 & 31 & 23 & 21 \\
\hline 4 & 0 & 0 & 30 & 32 & $0^{*}$ \\
\hline 5 & 2 & 25 & 31 & 37 & 5 \\
\hline 6 & 0 & 2 & 58 & 37 & $0^{*}$ \\
\hline Overall & $1 \pm 2$ & $15 \pm 10$ & $39 \pm 14$ & $28 \pm 14$ & $10 \pm 10$ \\
\hline
\end{tabular}

Two-dimensional intracoronary ultrasound imaging of the right coronary ostium was performed before and after coronary atherectomy in 1 patient with a $4.8 \mathrm{Fr}, 20$ $\mathrm{MHz}$ catheter-based imaging transducer (Boston Scientific/Diasonics, Watertown, Massachusetts).

Successful coronary atherectomy of the right coronary ostium was performed in 6 of 7 patients. In the remaining patient, despite successful predilation with standard coronary angioplasty, a $6 \mathrm{Fr}$ atherectomy device could not be positioned across the stenosis because the 9.5Fr guiding catheter provided insufficient backup. No patient developed in-hospital ischemic complications.

In patients with successful atherectomies, the percent diameter stenosis was reduced from $61 \pm 5$ to $14 \pm 16 \%$ and the minimal luminal diameter increased from $1.7 \pm$ 0.4 to $3.2 \pm 0.8 \mathrm{~mm}$ (Table I). Coronary arteriography was repeated in all patients $6.2 \pm 2.7$ months after successful atherectomy. One patient with an initial lesion length of $11.1 \mathrm{~mm}$, coronary calcific deposits and a residual $46 \%$ stenosis immediately after coronary atherectomy developed angiographic restenosis (follow-up percent diameter stenosis, $78 \%$ ). None of the remaining patients developed restenosis.

A total of 4 to 16 tissue fragments were obtained per specimen. Normal vessel wall was identified in 5 of 6 patients; 2 of these also had small amounts of adventitia (Table II). The major lesion components were fibrocellular $(39 \pm 14 \%)$ and sclerotic $(28 \pm 14 \%)$. Lipid-rich components were infrequent $(10 \pm 10 \%)$, and thrombus was rarely seen.

After predilation with standard coronary angioplasty methods, intracoronary imaging demonstrated extensive intimal thickening and atheroma in the region of the right coronary ostium (Figure 2). After coronary atherectomy, an asymmetric resection of the ostial lesion was identified, but significant residual atheroma was still noted.

The precise mechanism whereby coronary atherectomy results in improved coronary dimensions remains controversial. ${ }^{3,5}$ Whereas atheroma resection mediates at least some of these improvements in coronary dimensions, other mechanisms, such as mechanical dilatation by the 


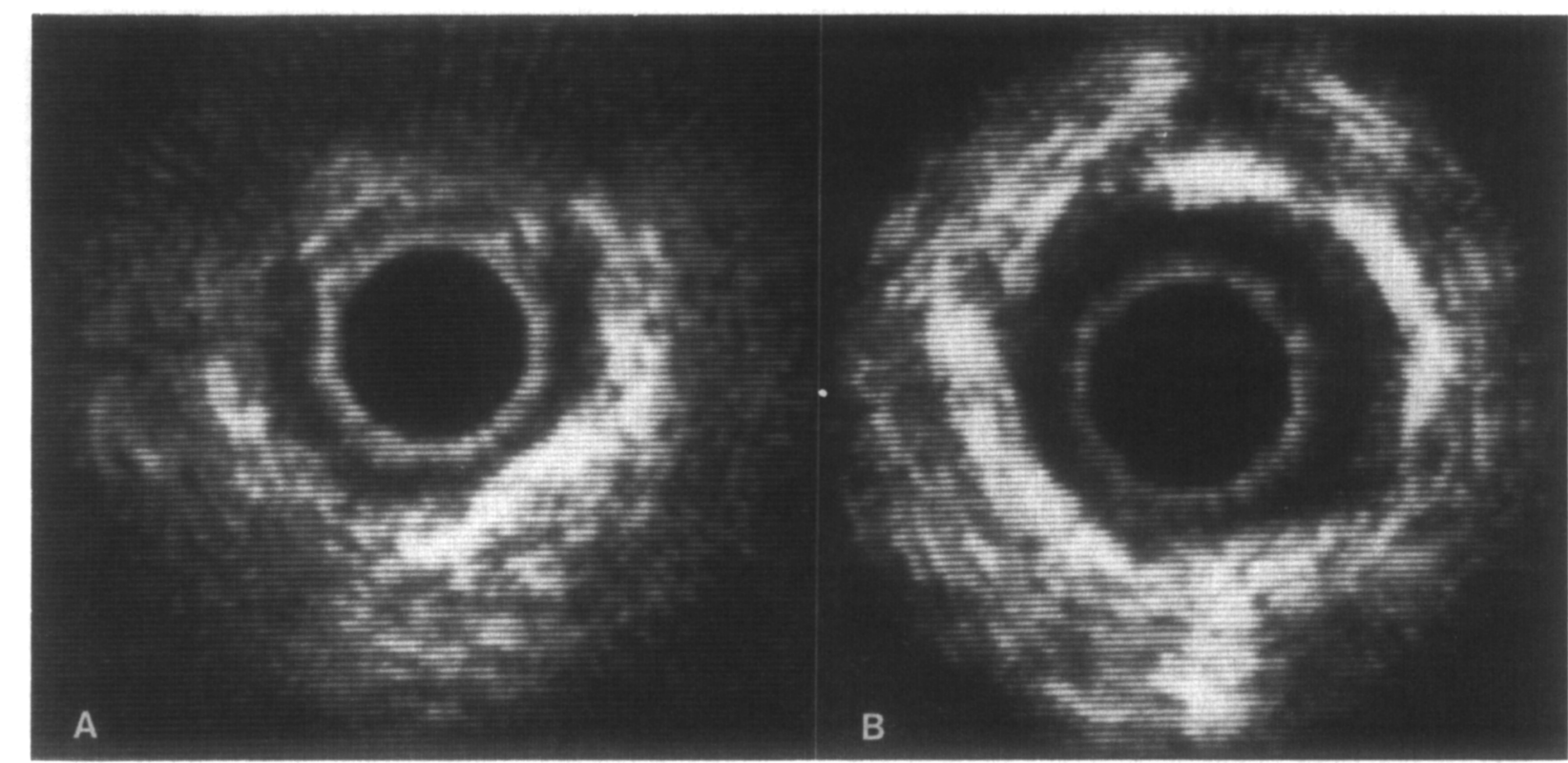

FIGURE 2. Two-dimensional intracoronary ultrasound image of the right coronary ostium after coronary angioplasty. A, the im." aging catheter with "ring-down" artifact is positioned in the center of the image. A hyperecho region is noted from 1 to 6 o'clock and is consistent with thickened intima and atheroma. Echo "drop-out" is seen from 10 to 12 o'clock as a result of coronary calcification. B, after directional atherectomy, the residual lesion in the coronary lumen has a scalloped appearance. Despite marked improvement in coronary dimensions, significant atheromatous tissue remains.

atherectomy device and barotrauma resulting from the unilateral balloon inflation, may also be operative. ${ }^{3,5}$ Using quantitative angiographic methods after coronary atherectomy, Safian et $\mathrm{al}^{3}$ demonstrated that the weight of tissue retrieved from the atherectomy device is insufficient to account fully for the angiographic improvement. In the present series, 4 to 16 tissue fragments were retrieved per specimen. Although not rigorously weighed, the size of the fragments was also insufficient to account for all of the improvement in coronary dimensions. Furthermore, despite the presence of media in 5 of 6 specimens, residual atheroma was observed with intracoronary ultrasound, suggesting that atheroma resection by coronary atherectomy is incomplete. Although the safety of deep tissue resection has been reported, ${ }^{6}$ more aggressive attempts at complete atheroma resection may result in coronary perforation ${ }^{7}$ without angioscopic or ultrasound guidance. ${ }^{8}$

Whereas restenosis after standard coronary angioplasty may occur more frequently in patients with right ostial stenoses than in other coronary lesions, ${ }^{1}$ restenosis has also been reported in nonostial stenoses after coronary atherectomy. ${ }^{3}$ Although randomized trials will be required to compare the long-term results of these 2 techniques for restenosis, the results of this pilot trial are encouraging. Further study into the role of coronary atherectomy in patients with right ostial stenoses is suggested.

In patients with right ostial stenoses, technical difficulties with guiding catheter intubation, lack of adequate backup, and inability to pass balloon dilatation catheters across the stenosis are major limitations seen with both coronary angioplasty and atherectomy. Further refinement in guiding catheter and device profile may result in improved procedural success rates. Furthermore, the adjunctive benefit of coronary atherectomy may be difficult to determine if predilation with standard coronary angioplasty is required. In the majority of patients in this pilot series, intraluminal haziness prevented application of standard computer-assisted edge detection algorithms to lesions after balloon dilatation. After coronary atherectomy, the arterial borders were more distinct, allowing application of the quantitative arterial program. Thus, in addition to its effects secondary to balloon dilatation, adjunctive atherectomy may permit removal of intracoronary debris and potentially provide a less platelet-reactive surface for subsequent platelet aggregation and thrombosis.

1. Topol EJ, Ellis SG, Fishman J, Leimgruber P, Myler RK, Stertzer SH, O'Neill WW, Douglas JS, Roubin GS, King SB. Multicenter study of percutaneous transluminal angioplasty for right coronary ostial stenosis. I Am Coll Cardiol 1987;9:1214 1218

2. Muller DW, Ellis SG, Debowey DL, Topol EJ. Quantitative angiographic comparison of the immediate success of coronary angioplasty, coronary atherectomy and endoluminal stenting. Am J Cardiol 1990;66:938-942.

3. Safian RD, Gelbfish JS, Erny RE, Schnitt SJ, Baim DS. Coronary atherectomy: clinical, angiographic, and histologic findings and observations regarding potential mechanisms. Circulation 1990;82:69-79.

4. Mancini GBJ, Simon SB, McGillem MJ, LeFree MJ, Friedman HZ, Vogel RA. Automated quantitative coronary arteriography: morphologic and physiologic validation in vivo of a rapid digital angiographic method. Circulation 1987; 75:452-460

5. Sharaf BL, Williams DO. "Dotter Effect" contributes to angiographic improvement following directional coronary atherectomy (abstr). Circulation 1990; 82(suppl III):III-310.

6. Garratt KN, Kaufman UP, Edwards WD, Vlietstra RE, Holmes DR. Safety of percutaneous coronary atherectomy with deep arterial resection. Am J Cardiol 1989;64:538-540.

7. U.S. Directional Coronary Atherectomy Study Group. Complications of directional coronary atherectomy in a multicenter experience (abstr). Circulation 1990;82:1II-311.

8. Yock PG, Linder DT, White NW, Rowe MH, Sclmon MR, Robertson GC, Hinohara T, Simpson JB. Clinical applications of intravascular ultrasound imaging in atherectomy. Int $J$ Card Imaging 1989;4:117-125. 